\title{
Analisis Validitas dan Reliabilitas Alat Peraga Tabung Resonansi Horisontal beserta Instrumennya untuk Menunjang Keterampilan Generik Sains Siswa
}

\author{
C. Huda*, F. F. Damayanti, dan D. Nuvitalia \\ Program Studi Pendidikan Fisika Universitas PGRI Semarang \\ *e-mail: choirulhuda@upgris.ac.id

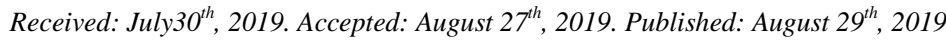

\begin{abstract}
Abstrak
Penelitian ini bertujuan untuk menguji kelayakan instrumen dan alat peraga tabung resonansi horisontal untuk menunjang keterampilan generik sains siswa. Instrumen yang digunakan dalam penelitian ini adalah lembar observasi dengan jumlah 10 aktivitas siswa yang diamati. Media pembelajaran yang digunakan adalah produk berupa alat peraga tabung resonansi horisontal dan pedoman penggunaan alat. Penelitian ini merupakan penelitian deskriptif kualitatif untuk menilai dan mengetahui kualitas instrumen serta alat peraga untuk menunjang keterampilan generik sains siswa. Instrumen dan alat peraga masingmasing divalidasi oleh dua ahli pendidikan fisika. Hasil penelitian menunjukkan: 1) rata-rata hasil validasi oleh kedua ahli berada pada kriteria sangat valid dengan persentase masing-masing sebesar $85,42 \%$ untuk lembar observasi, $91,67 \%$ untuk alat peraga tabung resonansi horisontal, dan $100 \%$ untuk pedoman penggunaan alat; 2 ) reliabilitas produk berada pada kriteria reliabel dengan persentase instrumen lembar observasi $88,23 \%$, alat peraga tabung resonansi horisontal 97,06\%, dan pedoman penggunaan alat $100 \%$. Berdasarkan hasil penelitian, instrumen dan alat peraga tabung resonansi horisontal layak digunakan untuk menunjang keterampilan generik sains siswa dengan kriteria sangat valid dan reliabel.
\end{abstract}




\begin{abstract}
The purpose of this research to determine the validity and reliability of instrument and horizontal resonance tubes props to support student's generic science skills. The instrument used in this research is the observation sheet with the number of 10 student activities observed. The learning media used are products in the form of horizontal resonance tube props and props usage guidelines. This research is a qualitative descriptive study to assess and determine the quality of instrument and props to support student's generic science skills. Each instrument and props were validated by two physics education experts. The results showed: 1) the average validation results by the two experts were in very valid criteria with a percentage of $85.42 \%$ for observation sheets, $91.67 \%$ for horizontal resonance tube props, and 100\% for usage guidelines tool; 2) product reliability is on the reliable criteria with the percentage of observation sheet instruments $88.23 \%$, horizontal resonance tube props $97.06 \%$, and guidelines for using the tools $100 \%$. Based on the results of the research, instruments and horizontal resonance are proper to be used to support students' generic science skills with very valid and reliable criteria. (C) 2019PERJ
\end{abstract}

Keywords: horizontal resonance tubes, props, science generic skills. 


\section{PENDAHULUAN}

Sains merupakan ilmu yang dibangun atas penyimpulan kejadian-kejadian yang ada di alam sehingga sains dapat dikategorikan sebagai ilmu yang bersifat induktif. Sains pada hakikatnya membelajarkan proses dan produk tentang kajian gejala alam yang bersifat analisis maupun pengamatan (Nuroso, Siswanto, dan Huda, 2018). Pembelajaran sains merupakan suatu proses yang dilakukan pendidik dan peserta didik dalam mempelajari gejala alam yang bertujuan memperoleh pengetahuan dan keterampilan. Pembelajaran sains khususnya fisika merupakan proses menggunakan metode ilmiah yang tidak hanya ditunjukkan oleh penguasaan dalam konsep maupun teori, tetapi juga perlu penguasaan dalam kecakapan berpikir dan bertindak secara ilmiah (Asy'ari, Ikhsan, dan Muhali, 2018).

Salah satu kecakapan berpikir dan bertindak secara ilmiah dapat tercermin dari keterampilan generik sains siswa. Keterampilan generik sains siswa sangat penting bagi siswa karena keterampilan ini tidak diperoleh secara tiba-tiba melainkan harus dilatih secara terus menerus (Martiningsih, Situmorang, dan Hastuti, 2018). Oleh sebab itu, penelitian yang bertujuan untuk meningkatkan

keterampilan generik sains siswa sering kali dilakukan. Beberapa di antaranya dilakukan oleh Agustin (2013), Darmawan et al. (2013), Gunawan et al. (2013), Warimun dan Murwaningsih (2015), Mukhlis, (2017), dan Rosidah et al. (2019).

Menurut Brotosiswoyo dalam Sudarmin (2012), keterampilan generik sains dapat dikategorikan menjadi sembilan indikator, yaitu: pengamatan langsung, pengamatan tidak langsung, kesadaran tentang skala, bahasa simbolik, logical frame, abstraksi, hukum sebab akibat, permodelan matematika, dan pembangunan konsep.

Instrumen penilaian dan media pembelajaran yang tepat diperlukan untuk menunjang keterampilan generik sains siswa. Instrumen penilaian digunakan sebagai alat bantu untuk mendapatkan hasil yang valid pada aspek yang dievaluasi. Instrumen penilaian dikatakan baik apabila mampu mengukur sesuatu dengan hasil seperti keadaan yang dievaluasi. Teknik evaluasi digolongkan menjadi dua macam, yaitu teknik tes dan teknik non tes. Teknik tes dapat berupa tes objektif maupun subjektif; sedangkan teknik non tes dapat berupa skala bertingkat, kuisioner, daftar cocok, wawancara, pengamatan, dan riwayat hidup. 
Teknik pengamatan adalah suatu teknik yang dilakukan dengan cara mengadakan pengamatan yang teliti serta pencatatan yang sistematis (Arikunto, 2013). Pengamatan dapat dilakukan dengan menggunakan instrumen lembar observasi.

Selain instrumen penilaian, penggunaan media juga mampu menunjang pembelajaran di sekolah. Salah satu media yang dapat digunakan dalam proses pembelajaran adalah alat peraga.

Alat peraga didefinisikan sebagai alat bantu untuk mendidik atau mengajar supaya konsep yang diajarkan guru mudah dimengerti oleh siswa dan menjadi pengantar pesan pembelajaran (Widyatmoko dan Pamelasari, 2012). Pembelajaran menggunakan alat peraga berarti mengoptimalkan fungsi seluruh indera siswa untuk meningkatkan efektivitas siswa belajar dengan cara mendengar, melihat, meraba, dan menggunakan pikirannya secara logis dan realistis.

Penggunaan alat peraga yang sesuai juga mampu memudahkan siswa dalam menunjang kegiatan pembelajaran. Alat peraga yang digunakan dalam penelitian ini adalah tabung resonansi horisontal. Alat peraga tabung resonansi horisontal mudah dan praktis untuk digunakan, namun tetap memuat konsep materi resonansi di dalamnya. Alat ini berbeda dengan alat resonansi yang biasa ditemui di sekolah yang cenderung susah untuk digunakan. Ketika sebuah alat peraga sulit digunakan, siswa akan mudah menyerah dalam melakukan proses praktikum/ percobaan yang akan berimbas pada lemahnya keterampilanketerampilan proses yang dipelajari dalam dunia sains, salah satunya keterampilan generik sains. Oleh karena itu, pemilihan alat peraga yang tepat juga dibutuhkan untuk menarik perhatian dan motivasi siswa selama proses pembelajaran serta menunjang keterampilan generik sains siswa (Susilawati et al., 2018).

Tabung resonansi horisontal adalah suatu alat peraga yang digunakan untuk menunjukkan gejala resonansi. Tabung resonansi horisontal juga memunyai fungsi untuk menentukan laju bunyi di udara. Alat pendukung tabung resonansi horisontal adalah frekuensi generator dan phyphox (saat ini keduanya bisa diunduh dengan mudah di Play Store). Frekuensi generator berperan sebagai sumber suara yang berupa frekuensi. Phyphox merupakan aplikasi yang digunakan untuk melihat output dari percobaan berupa amplitudo dari suara yang dihasilkan. Variasi yang digunakan dalam percobaan ini adalah pada variabel dari nilai frekuensi. Variasi dari nilai 
frekuensi untuk membuktikan bahwa berapapun nilai frekuensi dan panjang kolom udara yang dihasilkan, nilai laju bunyi di udara akan tetap sama.

Keterampilan menggunakan alat peraga dapat mencerminkan keterampilan generik sains yang dimiliki siswa. Hal ini dikarenakan beberapa indikator dalam keterampilan generik sains dapat diukur menggunakan instrumen penilaian berupa lembar observasi melalui kegiatan praktikum atau percobaan yang melibatkan penggunaan alat peraga di dalamnya. Oleh karena itu, dalam penelitian ini masalah pokok yang akan dikaji adalah validitas dan reliabilitas instrumen dan alat peraga tabung resonansi horisontal untuk menunjang keterampilan generik sains siswa.

\section{METODE PENELITIAN}

Metode yang digunakan dalam penelitian adalah deskriptif kualitatif untuk mengetahui nilai dan kualitas instrumen serta alat peraga tabung resonansi horisontal untuk menunjang keterampilan generik sains siswa. Validasi dilakukan terhadap instrumen penilaian keterampilan generik sains berupa lembar observasi dengan 10 aktivitas siswa, alat peraga tabung resonansi horisontal, serta pedoman penggunaan alat.
Pengujian validitas dilakukan melalui validasi ahli yang melibatkan masing-masing dua orang ahli di bidang pendidikan fisika. Analisis validitas instrumen dan alat peraga mengikuti Persamaan 1.

$$
P_{s}=\frac{n}{N} \times 100 \%
$$

Keterangan:

$\mathrm{P}_{\mathrm{s}}=$ persentase skor

$\mathrm{n}$ = jumlah skor yang diperoleh

$\mathrm{N}=$ jumlah skor maksimal

Selanjutnya, dari hasil analisis validasi para ahli, dihitung pernyataan yang sesuai dan tidak sesuai dengan aspek yang telah ditelaah. Kriteria penskoran dikonsultasikan dengan aturan yang disajikan pada Tabel 1 (Arikunto dan Jabar, 2009).

Tabel 1. Kriteria penskoran

\begin{tabular}{cl}
\hline Persentase & Kategori \\
\hline $81 \% \leq \mathrm{P}_{\mathrm{s}} \leq 100 \%$ & Sangat Valid \\
$61 \% \leq \mathrm{P}_{\mathrm{s}} \leq 80 \%$ & Valid \\
$41 \% \leq \mathrm{P}_{\mathrm{s}} \leq 60 \%$ & Cukup Valid \\
$21 \% \leq \mathrm{P}_{\mathrm{s}} \leq 40 \%$ & Kurang Valid \\
$\mathrm{P}_{\mathrm{s}} \leq 20 \%$ & Tidak Valid \\
\hline
\end{tabular}

Analisis reliabilitas instrumen dan alat peraga tabung resonansi horisontal dilakukan menggunakan percentage of agreement. Menurut Borich 1994 dalam Fitriyani dan Wiyatmo (2017), nilai reliabilitas dapat diketahui menggunakan Persamaan 2. 
Percentage Agreement $=$

$$
100 \% \times\left(1-\frac{A-B}{A+B}\right)
$$

Keterangan:

$\mathrm{A}=$ Frekuensi aspek tingkah laku yang teramati oleh pengamat dengan memberikan frekuensi tinggi.

$\mathrm{B}=$ Frekuensi aspek tingkahlaku yang teramati oleh pengamat memberikan dengan rendah.

Instrumen dan alat peraga dikatakan reliabel jika memiliki nilai percentage of agreement $\geq 75 \%$.

\section{HASIL DAN PEMBAHASAN}

Analisis validitas dan reliabilitas instrumen keterampilan generik sains dilakukan pada lembar observasi yang disesuaikan dengan sembilan indikator utama keterampilan generik sains dan media pembelajaran berupa alat peraga tabung resonansi horisontal dan pedoman penggunaan alat. Analisis validitas dan reliabilitas ang dilakukan adalah sebagai berikut:

\section{Lembar Observasi}

Lembar observasi yang digunakan disesuaikan dengan sembilan indikator keterampilan generik sains sehingga terdapat sepuluh aktivitas siswa yang diamati oleh observer. Lembar observasi terlebih dahulu divalidasi oleh ahli. Terdapat empat aspek dalam instrumen penilaian lembar observasi yang diberikan kepada kedua validator dengan nilai rata-rata sesuai pada Tabel 2.

Tabel 2. Hasil Validitas dan Reliabilitas Lembar Observasi

\begin{tabular}{lcc}
\hline \multicolumn{1}{c}{$\begin{array}{c}\text { Aspek } \\
\text { Penilaian }\end{array}$} & $\begin{array}{c}\text { Persentase } \\
\text { Tertinggi }\end{array}$ & $\begin{array}{c}\text { Persentase } \\
\text { Terendah }\end{array}$ \\
\hline Konstruksi & & \\
Isi & & \\
Bahasa & $95 \%$ & $75 \%$ \\
Teknis & & \\
\hline $\begin{array}{l}\text { Percentage of } \\
\text { Agreement } \\
(P A)\end{array}$ & $85.42 \%$ \\
\hline
\end{tabular}

Pada aspek konstruksi diperoleh persentase $83.33 \%$ dengan kriteria sangat valid, aspek isi diperoleh persentase $83.33 \%$ dengan kriteria sangat valid, aspek bahasa diperoleh persentase $87.50 \%$ dengan kriteria sangat valid, dan aspek teknis diperoleh persentase $87.50 \%$ dengan kriteria sangat valid. Secara rata-rata, keempat aspek penilaian tersebut mendapatkan persentase sebesar $85.42 \%$ sehingga instrumen soal uji coba yang telah divalidasi oleh kedua validator layak digunakan dengan kriteria sangat valid. Nilai reliabilitas diperoleh dari analisis menggunakan persamaan percentage of agreement dan didapatkan persentase sebesar 
88.23\% (lebih dari 75\%) sehingga lembar observasi yang telah divalidasi oleh kedua validator termasuk reliabel. Hasil persentase rata-rata validasi lembar soal uji coba oleh kedua ahli dapat dilihat dalam bentuk diagram batang pada Gambar 1 .

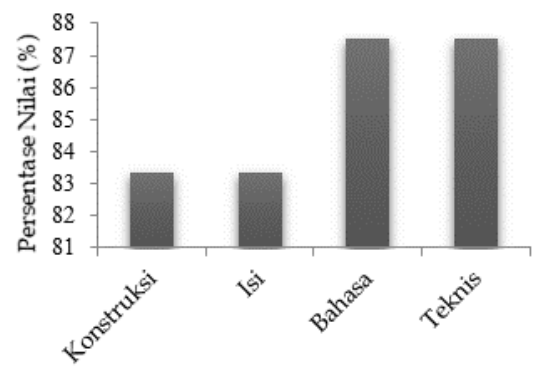

Gambar 1. Diagram Hasil Rata-Rata Validasi Instrumen Lembar Observasi oleh Kedua Ahli

\section{Alat Peraga Tabung Resonansi Horisontal}

Terdapat enam aspek dalam instrumen penilaian alat peraga tabung resonansi horisontal yang diberikan kepada kedua validator seperti disajikan pada Tabel 3.

Pada aspek ketahanan alat diperoleh persentase $87.50 \%$ dengan kriteria sangat valid, aspek kesesuaian materi diperoleh persentase $100 \%$ dengan kriteria sangat valid, aspek keakuratan alat diperoleh persentase $75 \%$ dengan kriteria valid, aspek teknis diperoleh persentase $100 \%$ dengan kriteria sangat valid, aspek keamanan diperoleh persentase $\quad 87.50 \%$ dengan kriteria sangat valid, dan aspek keterjangkauan diperoleh persentase $100 \%$ dengan kriteria sangat valid.

Tabel 3. Validitas dan Reliabilitas Alat Peraga

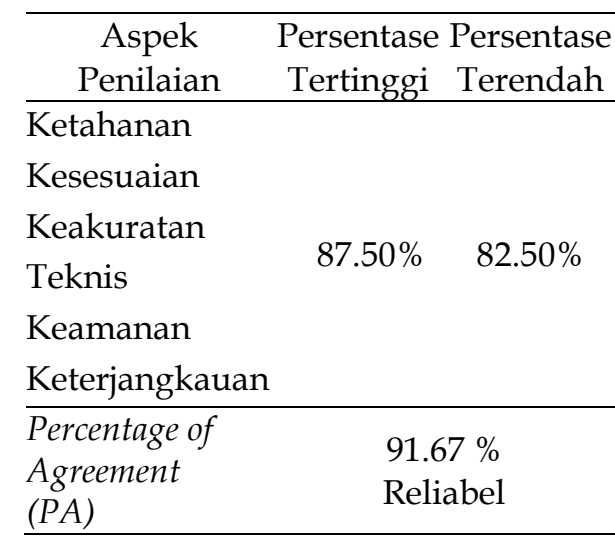

Alat peraga tabung resonansi horisontal yang telah divalidasi oleh kedua validator layak digunakan dengan kriteria sangat valid dan reliabel. Hasil persentase rata-rata validasi alat peraga tabung resonansi horisontal oleh kedua ahli dapat dilihat dalam bentuk diagram batang pada Gambar 2 .

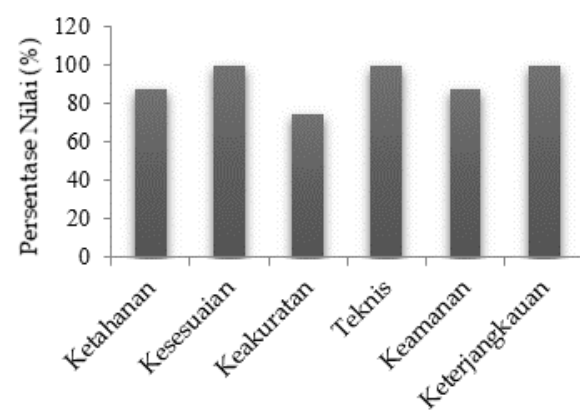

Gambar 2. Persentase Rata-rata Validasi Alat Peraga oleh Kedua Ahli 


\section{Pedoman Penggunaan Alat}

Terdapat dua aspek dalam instrumen penilaian pedoman penggunaan alat yang diberikan kepada kedua validator yang disajikan pada Tabel 4 .

Tabel 4. Hasil Validitas dan Reliabilitas Pedoman Penggunaan Alat

\begin{tabular}{lcc}
\multicolumn{1}{c}{$\begin{array}{c}\text { Aspek } \\
\text { Penilaian }\end{array}$} & $\begin{array}{c}\text { Persentase } \\
\text { Tertinggi }\end{array}$ & $\begin{array}{c}\text { Persentase } \\
\text { Terendah }\end{array}$ \\
\hline $\begin{array}{l}\text { Penulisan } \\
\text { Kebahasaan }\end{array}$ & $100 \%$ & $100 \%$ \\
\hline $\begin{array}{l}\text { Percentage of } \\
\text { Agreement } \\
(P A)\end{array}$ & \multicolumn{2}{c}{$\begin{array}{c}100 \% \\
\text { Reliabel }\end{array}$} \\
\hline
\end{tabular}

Penilaian rata-rata yang diberikan oleh kedua validator untuk pedoman penggunaan alat pada aspek penulisan diperoleh persentase $100 \%$ dengan kriteria sangat valid dan pada aspek kebahasaan diperoleh persentase $100 \%$ dengan kriteria sangat valid. Secara rata-rata kedua aspek penilaian tersebut mendapatkan persentase sebesar $100 \%$ sehingga pedoman penggunaan alat yang telah divalidasi oleh kedua validator layak digunakan dengan kriteria sangat valid. Nilai reliabilitas diperoleh dari analisis menggunakan persamaan percentage of agreement dan didapatkan persentase lebih dari 75\% sehingga pedoman penggunaan alat yang telah divalidasi oleh kedua validator termasuk kriteria reliabel. Hasil persentase rata-rata validasi pedoman penggunaan alat oleh kedua ahli dapat dilihat dalam bentuk diagram batang pada Gambar 3.

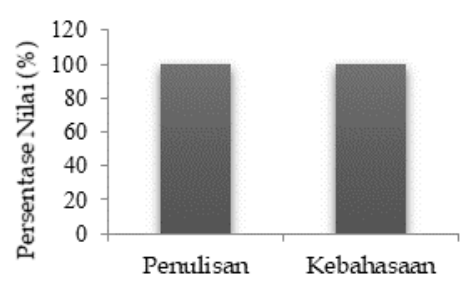

Gambar 3. Diagram Hasil Rata-Rata Validasi Pedoman Penggunaan Alat oleh Kedua Ahli

\section{KESIMPULAN}

Berdasarkan hasil analisis dan pembahasan pada penelitian ini dapat disimpulkan bahwa instrumen observasi keterampilan generik sains dalam bentuk lembar observasi dengan sepuluh aktivitas siswa yang diamati yang disesuaikan dengan sembilan indikator keterampilan generik sains valid dan reliabel dengan perolehan persentase rata-rata validitas $85.42 \%$ dengan kriteria sangat valid serta percentage of agreement $88.23 \%$ dengan kriteria reliabel. Selain itu, alat peraga tabung resonansi horisontal dan pedoman penggunaan alat juga valid dan reliabel dengan perolehan persentase rata-rata validitas $91.67 \%$ dengan kriteria 
sangat valid dan 100\% dengan kriteria sangat valid serta percentage of agreement $96.07 \%$ dan $100 \%$ dengan kriteria reliabel sehingga instrumen penilaian dan alat peraga tabung resonansi horisontal layak digunakan untuk menunjang keterampilan generik sains siswa.

\section{UCAPAN TERIMA KASIH}

Ucapan terimakasih kami sampaikan kepada ketua Program Studi Pendidikan Fisika Universitas PGRI Semarang yang telah memberikan izin untuk melakukan penelitian dan pengembangan produk.

\section{DAFTAR PUSTAKA}

Agustin, R. 2013. Pengembangan

Keterampilan Generik Sains melalui Penggunaan Multimedia Interaktif. Jurnal Pengajaran MIPA, 18(2), 253257.

Arikunto, S. 2013. Dasar-dasar Evaluasi Pendidikan. Jakarta: Bumi Aksara.

Arikunto, S. dan Jabar, C. S. 2009. Evaluasi Program Pendidikan. Jakarta: Bumi Aksara.

Asy'ari, M., Ikhsan, M., dan Muhali. 2018. Validitas Instrumen Karakterisasi Kemampuan Metakognisi Mahasiswa Calon Guru Fisika. Prima Sains: Jurnal
Pengkajian Ilmu dan

Pembelajaran Matematika dan IPA IKIP Mataram, 6(1), 1826.

Darmawan, J., Halim, A., dan Nur, S. 2013. Metode Pembelajaran Eksperimen Berbasis Inkuiri untuk Meningkatkan Pemahaman Konsep dan Keterampilan Generik Sains Siswa SMA. Jurnal Pendidikan Sains Indonesia (JPSI), 22-33.

Fitriyani, L. dan Wiyatmo, Y. 2017. Pengembangan Media Pembelajaran VLOG (Video Blogging) pada Materi Usaha dan Energi untuk Menumbuhkan Kemandirian dan Meningkatkan

Penguasaan Konsep Fisika Siswa Kelas X SMA Negeri 2 Ngaglik. Jurnal Pedidikan Fisika, 6, 427-435.

Gunawan, Setiawan, A., dan Widyantoro, D. H. (2013). Model Virtual Laboratory Fisika Modern untuk Meningkatkan Keterampilan Model Virtual Laboratory Fisika Modern untuk Meningkatkan Keterampilan Generik Sains Calon Guru. Jurnal Pendidikan dan Pembelajaran, 20(1), 25-32.

Martiningsih, M., Situmorang, R. P., dan Hastuti, S. P. 2018. Hubungan Keterampilan Generik Sains dan Sikap Ilmiah melalui Model Inkuiri Ditinjau dari Domain 
Kognitif. Jurnal Pendidikan Sains (JPS), 06(01), 24-33.

Mukhlis. 2017. Pembelajaran

Model Inquiri Terbimbing pada Materi Besaran dan Satuan untuk Meningkatkan Keterampilan Generik Sains dan Hasil Belajar Mahasiswa. Lantanida Journal, 5(1), 29-41.

Nuroso, H., Siswanto, J., dan Huda, C. 2018. Developing a Learning Model to Promote The Skills of Analytical Thinking. Journal of Education and Learning (EduLearn), 12(4), 775-780.

Rosidah, T., Hidayah, F. F., dan Astuti, A. P. 2019. Efektivitas Model Problem Based Instruction Berpendekatan Etnosains untuk Meningkatkan Keterampilan Generik Sains. Jurnal Pendidikan Sains (JPS), 7(1), 14-21.

Sudarmin. 2012. Keterampilan Generik Sains dan
Penerapannya dalam

Pembelajaran Kimia Organik.

Semarang: Unnes Press.

Susilawati, Huda, C., Kurniawan, W., Masturi, dan Khoiri, N. 2018. Analysis of pre-service physics teacher skills designing simple physics experiments based technology. J Phys: Conf Ser 983012045.

Warimun, E. S., \& Murwaningsih, A. 2015. Model Pembelajaran Induktif untuk Meningkatkan Pemahaman Konsep dan Keterampilan Generik Fisika Siswa SMA. Jurnal Penelitian dan Pengembangan Pendidikan Fisika (JPPPF), 1(1), 105-110. Widyatmoko, A dan Pamelasari, S. D. 2012. Pembelajaran Berbasis Proyek untuk Mengembangkan Alat Peraga IPA dengan Memanfaatkan Bahan Bekas Pakai. Jurnal Pendidikan IPA Indonesia, 51-56. 